\title{
RESEARCH OF ELECTROMECHANICAL SYSTEM OF VIBROCOMPACTOR WITH A CHAOTIC ESTABLISHED OPERATING MODE
}

O. Mykhailenko, V. Tytiuk

State Institution of Higher Education "Kryvyi Rih National University"

ul. Vitaliya Matusevycha, 11, Kryvoy Rog, 50027, Ukraine. E-mail: epem.mykhailenko@gmail.com

O. Chornyi, E. Burdilna, A. Oksanich

Kremenchuk Mykhailo Ostrohradskyi National University

ul. Pervomayskaya, 20, Kremenchug, 39600, Ukraine. E-mail: alekseii.chornyi@gmail.com

Purpose. The article is devoted to the researching the possibility of creating chaotic regimes for the motion of the electromechanical vibrocompactor of the crucible induction furnace lining in order to improve the quality of the lining, which largely determines the technical and economic parameters of the iron production process. Originality. A method is proposed for the formation of a chaotic operating mode of the electric drive of a vibrocompactor by applying a sinusoidal function from the delay in the feedback circuit in the speed of the electric drive. The dependence of the chaotic operation parameters on the parameters of the closed control system during the operation of the electric drive as in a system with a power supply of infinite power is determined, taking into account the limitation of boosting the supply voltage. Methodology. In the study of the tasks, general methods of the theory of electric drive, electrical engineering and mathematical modeling were used. The compilation of the equations of a mathematical model of a vibrocompactor with an electric DC drive is based on the application of approved laws of mechanics and electrical engineering. The solution of the equations obtained and the visualization of the results obtained are performed in the MATLAB/Simulink environment. Results. A mathematical model of the mechanical system of a vibrocompactor is developed, taking into account the lining damping ability. As the vibrocompactor electric drive, a DC motor of independent excitation is adopted. As a result of the analysis of known methods of excitation of the regime of chaotic oscillations in electromechanical systems for lining vibrocompactor, a sinusoidal function was used from the delayed feedback on the speed of the electric drive. The results of mathematical modeling of the operating modes of the electromechanical system of a vibrocompactor with a closed loop system are given, the conditions for the appearance of a chaotic operating mode are determined, the dependence of the chaotic operating mode parameters on the feedback control parameters of a closed control system is considered. Practical value. The use of the proposed approach will simplify the design of the mechanical part of the vibrocompactor electric drive, increase the density of the lining of the crucible induction furnaces, and improve the technical and economic parameters of the cast iron production process. References 14, tables 3, figures 10.

Key words: vibrocompactor, chaos, electric drive, feedback, delay, MATLAB.

\section{ДОСЛІДЖЕННЯ ЕЛЕКТРОМЕХАНІЧНОЇ СИСТЕМИ ВІБРОУЩІЛЬНЮВАЧА З ХАОТИЧНИМ КВАЗІУСТАЛЕНИМ РЕЖИМОМ РОБОТИ}

\section{О. Ю. Михайленко, В. К. Титюк}

Державний вищий навчальний заклад «Криворізький національний університет» вул. Віталія Матусевича, 11, м. Кривий Ріг, 50027, Україна. E-mail: epem.mykhailenko@ gmail.com

О. П. Чорний, С. В. Бурдільна, А. П. Оксанич

Кременчуцький національний університет імені Михайла Остроградського

вул. Першотравнева, 20, м. Кременчук, 39600, Україна. E-mail: alekseii.chornyi@gmail.com

Робота присвячена питанню дослідження можливості створення хаотичних режимів руху електромеханічної системи віброущільнювачів футерування тигельних індукційних печей з метою підвищення якості футеровки, яка багато в чому визначає техніко-економічні показники процесу виробництва чавуну. Запропоновано метод формування хаотичного режиму роботи електроприводу віброущільнювачів шляхом застосування синусоїдальної функції від запізнювання в колі зворотного зв’язку по швидкості електроприводу. Встановлено залежність показників хаотичного режиму роботи від параметрів замкнутої системи керування при роботі електропривода, як в системі з джерелом живлення нескінченної потужності, так і з урахуванням обмеження форсування напруги живлення. У дослідженні поставлених завдань використовувалися загальні методи теорії електроприводу, електротехніки і математичного моделювання. Складання рівнянь математичної моделі віброущільнювачів 3 електроприводом постійного струму заснованих на застосуванні апробованих законів механіки і електротехніки. Рішення отриманих рівнянь і візуалізація отриманих результатів виконана в середовищі MATLAB/Simulink. Розроблено математичну модель механічної системи віброущільнювача 3 урахуванням демпфуючої здатності футерування. У якості електроприводу віброущільнювача прийнятий двигун постійного струму незалежного збудження. У результаті аналізу відомих методів збудження режиму хаотичних коливань в електромеханічних системах для віброущільнювачів футерування була використана синусоїдальна функція від затриманого зворотного зв'язку за швидкістю електроприводу. Наведено результати математичного моделювання режимів роботи електромеханічної системи віброущільнювача із замкнутою системою керування, визначені умови виникнення хаотичного режиму роботи, розглянуто залежність 
показників хаотичного режиму роботи від налаштувань кола зворотного зв'язку замкнутої системи керування. Використання запропонованого підходу дозволить спростити конструкцію механічної частини електроприводу віброущільнювача, підвищити щільність футерування тигельних індукційних печей, покращити технікоекономічні показники процесу виробництва чавуну.

Ключові слова: віброущільнювач, хаос, електропривод, зворотний зв'язок, запізнювання, MATLAB.

PROBLEM STATEMENT. Increasing the efficiency of the technological processes of ferrous metallurgy is one of the most priority areas in the modernization of industrial facilities. The use of crucible induction furnaces in the production of pig iron enables to improve the quality and durability of the finished product. The design features of this type of furnace make it possible to broadly automate the melting process, which provides reserves to improve resource and energy efficiency.

The critical element of the melting unit is a refractory lining that protects the installation elements from the effects of high temperatures. The quality of lining determines the operation life of the furnace, its performance, reducing the cost of conducting the process, improving the quality of cast iron.

For the lining of the working space of the induction crucible furnace in the casting of pig-iron, quartzite with a maximum content of silica (not less than $97.5 \%$ ) and low alumina content (not more than $1.2 \%$ ) and iron oxides (not more than $0.6 \%$ ) with the addition of boron anhydride, which provides the best conditions for sintering the working layer of lining [1]. In this case, the most important step is the primary filling of the bottom of the crucible with lining and subsequent sealing. In the course of trampling, the lining should be provided with a bulk density of $2-2.1 \mathrm{~kg} / \mathrm{dm}^{3}$ [1]. Failure to observe this condition leads to bundle of quartzite mass, and as a consequence, to increase the level of wear of the crucible of the induction furnace.

Sealing of lining can be done in two ways: manually or using vibration electric seals. In [2], it is proposed to use a mechanical vibration system when consolidating the bulk environment, which implements the principle of applying the theory of deterministic chaos. The design of the developed vibro-exciter is a triple pendulum, which includes three rotating eccentrics. The main eccentric is driven by an unregulated electric drive. Other eccentric elements of the system through the conrods are consistently connected to each other. Experimental studies have shown that the use of such a vibration device can increase the density of the environment by $12.2 \%$ compared with standard methods. As an alternative to a mechanical vibroexciter, which has a rather complicated structure and low reliability, the authors in [3] developed a vibrating device in which the chaos of oscillations is achieved by means of an automated electric drive. In this case, the vibro-exciter agent includes only one eccentric, connected to the conrod.

It is expedient to carry out the chaotic motion of a vibrating tamper due to the formation of a chaotic mode of operation of its electromechanical system [3]. At the present time there are many of methods that allow to realize this task. In [4], on the example of a synchronous motor with permanent magnets, the method of forming a chaotic mode of operation by introducing a delay [5] in the circle of feedback on the speed is given. In $[6,7]$, suggested using a sinusoidal function from delayed feedback on a control parameter. In [8], the sinusoidal function was replaced with rectangular and pollen periodic functions in the formation of a chaotic operating mode of the direct current motor. The research [3] is devoted to the development of the method of generation of chaos by introducing into the law of control of the system with the feedback of an additional control action in the form of a sinusoidal function from the variable state of the system. In [9] the method of formation of chaotic mode in a linear system is considered due to switching at certain moments of the time of a piecewise-linear regulator.

The aim of the article is to study the modes of vibrating tamper of a crucible induction furnace with a chaotic character of the electric drive motion.

EXPERIMENTAL PART AND RESULTS OBTAINED. Development of mathematical model of vibrating tamper. The vibrating tamper is a mechanical system with a single degree of freedom, which is represented by the total weight of a metal plate and a vibration drive placed on it. The damping ability of quartzite lining is characterized by the stiffness coefficient $k$ and coefficient of resistance $c$. Dynamic properties of a vibrating tamper are described by the following differential equation [10]:

$$
m_{\Sigma} \frac{d^{2} x}{d t^{2}}+c \frac{d x}{d t}+k x=F(t),
$$

where $x$ is the position of the vibrating tamper relative to the equilibrium point; $F(t)$ - an exciting force. With the application of an electromechanical vibro-exciter, it is advisable to obtain the excitatory force by using an unbalanced mass (debalance), which is located on the shaft of the electric motor and rotates with it. As a result, according to [11], the stimulus force is in accordance with the equation:

$$
F(t)=F_{m} \sin (\omega t)
$$

where $F_{m}=m_{\Sigma} \omega^{2} r-$ amplitude value of force; $\omega$ - rotation frequency of the balance; $r$ - eccentricity; $m_{\Sigma}$ - the mass of the electromechanical system of vibrating tamper.

As an electric motor, a DC motor is proposed with excitation from permanent magnets. These engines are simpler in modeling and driving, and also characterized by a significantly lower mass compared to DC motors with an excitation winding. The last feature is decisive, due to the need to use a winch for the descent and lifting of the vibrating tamper in the crucible of the induction 
furnace, as well as its movement inside the working space of the unit.

The model of the DC motor was represented by the following system of equations [12]:

$$
\left\{\begin{array}{l}
u_{a}=L_{a \Sigma} \frac{d i_{a}}{d t}+R_{a \Sigma} i_{a}+E_{a} \\
E_{a}=k_{E} \omega \\
J \frac{d \omega}{d t}=M-M_{l} \\
M=k_{m} i_{a},
\end{array}\right.
$$

where $u_{a}$ - the armature voltage; $i_{a}$ - armature current; $R_{a \Sigma}$ - total resistance of the armature; $L_{a \Sigma}$ - total inductance of the armature; $E_{a}$ - EMF the armaturer; $k_{E}$ - coefficient of EMF; $k_{m}$ - coefficient of torque; $M$ - torque of the motor; $M_{l}$ - torque of resistance exercise; $\omega-$ rotation frequency.

Combining the equations (1)-(3) we obtain the mathematical model of the vibrating tamper of the induction furnace. The model constructed on equations (1)-(3) is non-autonomous. In [13], in order to simplify the interpretation of the results of computational experiments, it is recommended to study chaotic processes as stationary, therefore the resulting model should be brought to autonomous form. To do this, we introduce an additional variable [13], which characterizes the position of the engine shaft. As a result, the equation for determining the excitatory force takes the form:

$$
F(t)=F_{m} \sin (\theta)
$$

and

$$
\frac{d \omega}{d t}=\theta .
$$

So, taking into account the replacement $\omega t \rightarrow \theta$, the resulting vibrating tamper model:

$$
\left\{\begin{array}{l}
m_{\Sigma} \frac{d^{2} x}{d t^{2}}+c \frac{d x}{d t}+k x=F(t) \\
F(t)=F_{m} \sin (\theta) \\
\frac{d \omega}{d t}=\theta \\
u_{a}=L_{a \Sigma} \frac{d i_{a}}{d t}+R_{a \Sigma} i_{a}+E_{a} \\
E_{a}=k_{E} \omega \\
J \frac{d \omega}{d t}=M-M_{l} \\
M=k_{m} i_{a} .
\end{array}\right.
$$

When the computational experiments for the model (6) were carried out, the parameters of the mechanical system in the process unit were set up: $k=62.55 \cdot 10^{5} \mathrm{~N} / \mathrm{m} ; c=234.06(\mathrm{~N} \cdot \mathrm{s}) / \mathrm{m} ; m_{u}=2 \mathrm{~kg} ;$ $r=0.01 \mathrm{~m} ; \quad \Omega_{0}=70.94 \quad \mathrm{rad} / \mathrm{s} ; \quad c_{\max }=1.763 \cdot 10^{3}$; $\xi=0.1327 ; \delta=9.4166$. Here $\Omega_{0}-$ own frequency; $\xi$ - the damping coefficient; $\delta$ - the attenuation coefficient; $m_{u}$ - mass of unbalance.

In Fig. 1, the amplitude-frequency characteristic of the system is set at an earthquake force of $0.1 \mathrm{kN}$ and the frequency of the enveloped debalance is 0 to $400 \mathrm{rad} / \mathrm{s}$.

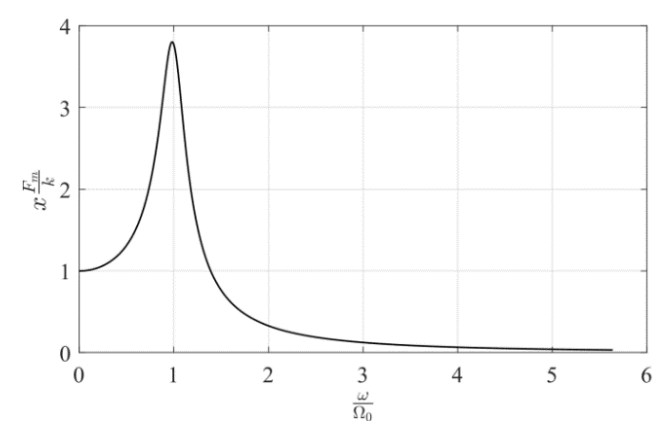

Figure 1 - Characteristics of the mechanical system vibrating tamper

The graph shows that when $\omega=\Omega_{0}$ a resonance occurs in the system, it is necessary to use a motor with a nominal rotation frequency that does not correspond to its own. According to [10], $\omega<\Omega_{0}$ the effect of excitatory force on vibration processes is negligible, that is, the drive frequency must be exceeded. Given that when vibrating tamper is a high amplitude of oscillation is undesirable [10], then, based on the amplitudefrequency characteristic, it is advisable to take a drive with a rotation frequency of about $2 \Omega_{0}$.

Proceeding from the foregoing in the course of research, an electric motor of the brand C42-L90 with nominal parameters [14] was used: $U_{n o m}=90 \mathrm{~V}$; $P_{\text {nom }}=0.359 \mathrm{~kW} ; \quad I_{\text {nom }}=5 \mathrm{~A} ; \quad n_{\text {nom }}=1500 \mathrm{rpm}$; $\eta=90 \% ; \quad J=0.00218907 \mathrm{~kg} \cdot \mathrm{m}^{2} ; \quad R_{a}=1.45 \mathrm{Om} ;$ $L_{a}=5.4 \mathrm{mH} ; \quad m_{m}=7.428 \mathrm{~kg} ; k_{M}=0.5791 \mathrm{~N} \cdot \mathrm{m} / \mathrm{A}$; $k_{E}=0.573 \mathrm{~V} / \mathrm{rpm}$.

In this paper, for the creation of a chaotic character of the motion of an electric drive, it is proposed to use the first method through the simplicity of its practical implementation. By analogy with the control law for the current circuit developed in [3], we propose a control law in a closed-loop control system with a feedback device at a rotation frequency at which the error applied to the input of the rotation frequencies controller is determined according to the equation:

$$
e_{\omega}=u_{\omega}-K_{\omega} \sin \left(K_{\tau} \omega(t-\tau)\right)-K_{\text {offset }},
$$

where $u_{\omega}$ - the signal of the task at rotation frequency; $K_{\omega}$ - the coefficient of $f$ feedback on the rotation frequency; $K_{\tau}$ - coefficient gain at rotation frequency; $K_{\text {offset }}$ - coefficient bias; $\tau$ - the value of delay.

To conduct research on the equations (1)-(7), an imitation model was compiled in MATLAB / Simulink environment, the structural scheme of which is shown in Fig. 2. 


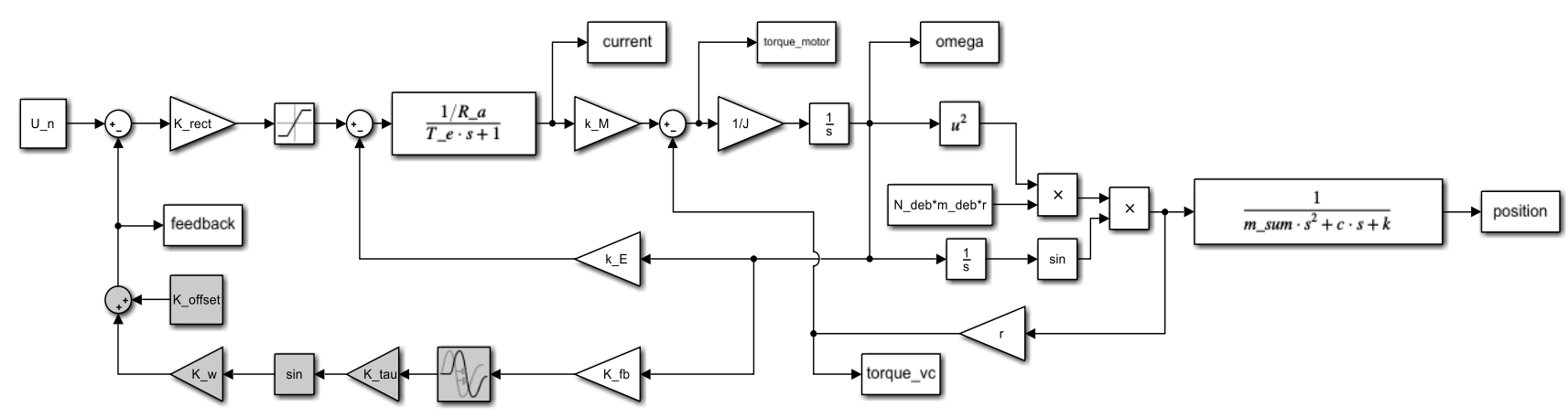

Figure 2 - The simulation model of the vibrating tamper of the induction furnace, which includes elements of the formation of a chaotic mode of operation

Initially, computational experiments were carried out in the absence of a voltage limitation element model (the Saturation block is excluded). To solve the system of differential equations, the method ode4 (RungeKutta) was used with a calculation step of $10^{-4}$.

In Fig. 3, 4 respectively, the temporal characteristics of the change in the rotation frequency and the phase trajectory of the vibrating tamper are given in the application of the law (7) with the following parameters $\tau=0.3 \mathrm{~s}, \quad K_{\tau}=3, \quad K_{\omega}=1$. Fidure indicate the occurrence of chaotic operating mode in the system.

In Tabl. 1 shows the parameters of the rotation frequency of the electric drive and the position of the vibrating tamper when the delay value is changed.

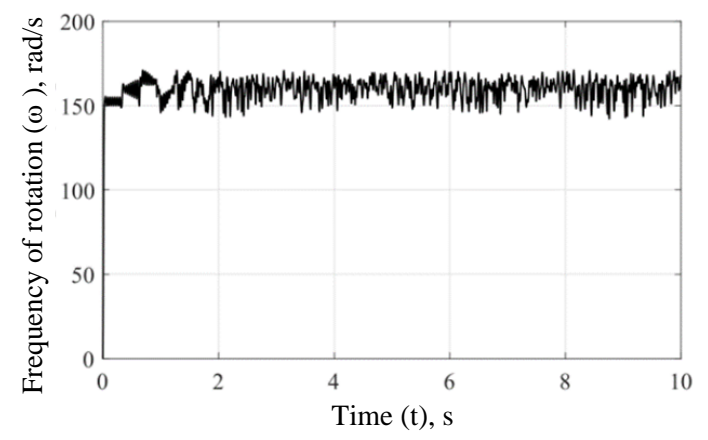

Figure 3 - Hourly realization of chaotic mode on the rotation frequency in the electric drive of the vibrating tamper at $\tau=0.3 \mathrm{~s}, K_{\tau}=3, K_{\omega}=1$

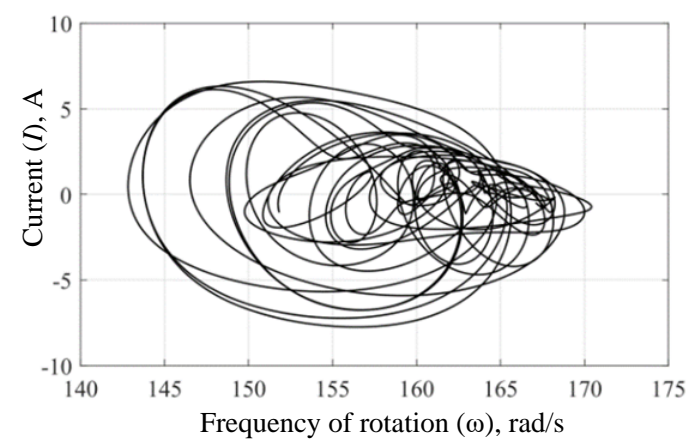

Figure 4 - Phase portrait of a vibrating tamper in a chaotic mode at $\tau=0.3 \mathrm{~s}, K_{\tau}=3, K_{\omega}=1$
Table 1 - Modeling results for $\tau=$ var,$K_{\tau}=3=$ const ,

$$
K_{\omega}=1=\mathrm{const}
$$

\begin{tabular}{|l|l|l|c|c|c|}
\hline$\tau, \mathrm{s}$ & $\begin{array}{c}\omega_{\min }, \\
\mathrm{rpm}\end{array}$ & $\begin{array}{c}\omega_{\max }, \\
\mathrm{rpm}\end{array}$ & $\begin{array}{c}\Delta \omega, \\
\mathrm{rpm}\end{array}$ & $\begin{array}{c}\bar{\omega}, \\
\mathrm{rpm}\end{array}$ & $\begin{array}{c}\Delta x, \\
\mathrm{~mm}\end{array}$ \\
\hline 0.1 & 144.69 & 170.24 & 25.55 & 159.84 & 7.21 \\
\hline 0.2 & 144.75 & 170.57 & 25.82 & 160.62 & 7.29 \\
\hline 0.3 & 143.22 & 170.71 & 27.49 & 159.83 & 7.32 \\
\hline 0.4 & 142.93 & 170.52 & 27.59 & 159.92 & 7.39 \\
\hline 0.5 & 142.16 & 170.79 & 28.63 & 160.46 & 7.43 \\
\hline 0.6 & 141.43 & 170.79 & 29.13 & 160.24 & 7.48 \\
\hline 0.7 & 170.9 & 170.8 & 29.89 & 160.03 & 7.54 \\
\hline
\end{tabular}

The results indicate an increase in the range of change in the rotation frequency spewith increasing delay. In this case, the average value of the angular velocity remains practically unchanged. It should be noted that the equation of the range of changes in the chaotic mode of movement occurs due to lowering the value of the lower boundary of the range with virtually unchanged top.

At the next stage, a change in the coefficient of delay enhancement was made.

When $K_{\tau}=1$ chaotic motion does not occur (Fig. 5). After $t=3.73 \mathrm{~s}$ harmonic oscillations with amplitude of $16.5 \mathrm{rad} / \mathrm{s}$ are established and the average value of the rotation frequency above nominal (Fig. 6).

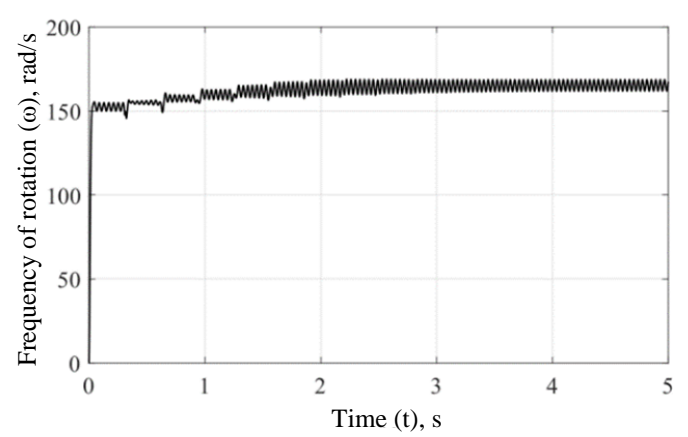

Figure 5 - Time implementation of the rotation frequency of the electric drive vibrating tamper at $\tau=0.4 \mathrm{~s}, K_{\tau}=1, K_{\omega}=1$ 


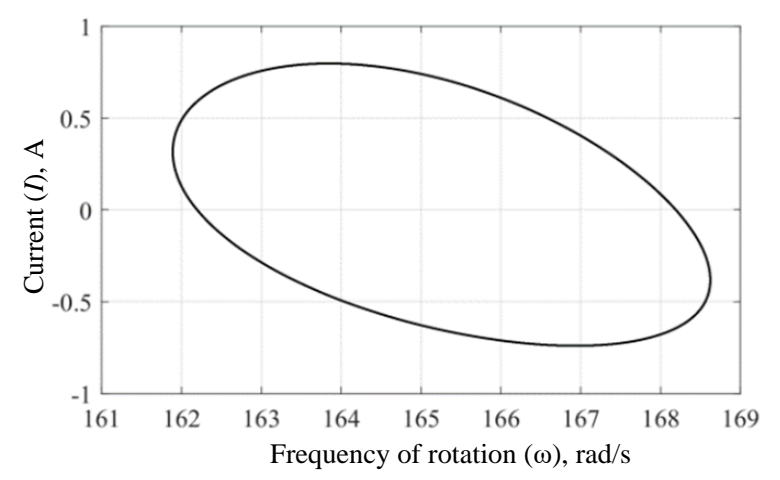

Figure 6 - Phase portrait of the vibrating tamper electric drive at $\tau=0.4 \mathrm{~s}, K_{\tau}=1, K_{\omega}=1$

When $K_{\tau}=2$ a chaotic motion with a harmonic component is formed (Fig. 7). The phase portrait has two areas in which there is a chaotic rotation mode with average values $\bar{\omega}_{1}=140.02 \mathrm{rev} / \mathrm{s}$ and $\bar{\omega}_{1}=167.5 \mathrm{rev} / \mathrm{s}$.

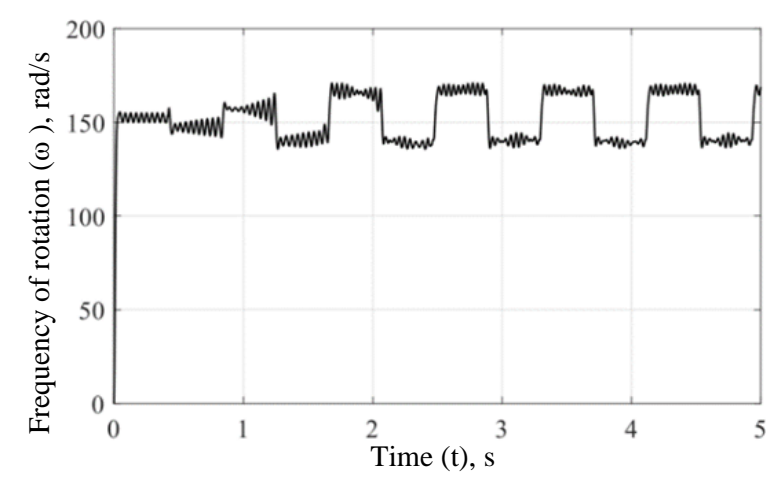

Figure 7 - Hourly realization of chaotic mode on the rotation frequency in the electric drive of a vibrating tamper at $\tau=0.4 \mathrm{~s}, K_{\tau}=2, K_{\omega}=1$

On each half-period, a transition from one trajectory of motion to another occurs (Fig. 8). So, the next simulation should be done with $K_{\tau}>2$.

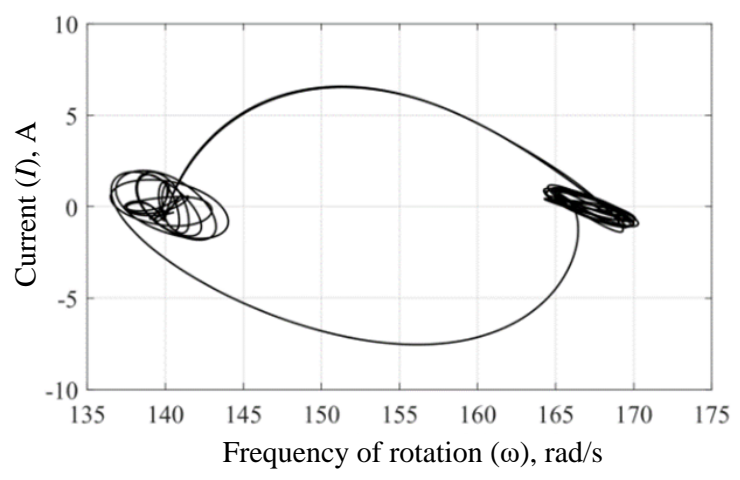

Figure 8 - Phase portrait of a vibrating tamper in a chaotic mode at $\tau=0.4 \mathrm{~s}, K_{\tau}=2, K_{\omega}=1$
Indicators of the rotation frequency and position of the vibrating tamper with a change in the coefficient of delay within the limits $\left\{K_{\tau} \in \mathbb{R} \mid 2 \leq K_{\tau} \leq 7\right\}$ of Tabl. 2 .

Table 2 - Modeling results for $K_{\tau}=$ var, $\tau=0.4 \mathrm{~s}=$ const,$K_{\omega}=1=$ const

\begin{tabular}{|l|l|l|l|c|l|}
\hline$K_{\tau}$ & $\begin{array}{c}\omega_{\min }, \\
\mathrm{rpm}\end{array}$ & $\begin{array}{c}\omega_{\max }, \\
\mathrm{rpm}\end{array}$ & $\begin{array}{c}\Delta \omega, \\
\mathrm{rpm}\end{array}$ & $\begin{array}{c}\bar{\omega}, \\
\mathrm{rpm}\end{array}$ & $\begin{array}{c}\Delta x, \\
\mathrm{~mm}\end{array}$ \\
\hline 2 & 135.68 & 170.9 & 35.22 & 153.22 & 6.89 \\
\hline 3 & 142.93 & 170.52 & 27.59 & 159.92 & 7.39 \\
\hline 4 & 135.09 & 170.38 & 35.29 & 152.66 & 7.73 \\
\hline 5 & 137.76 & 168.85 & 34.1 & 151.35 & 7.71 \\
\hline 6 & 135.71 & 170.13 & 34.42 & 152.44 & 7.59 \\
\hline 7 & 135 & 168.26 & 33.26 & 151.83 & 7.71 \\
\hline
\end{tabular}

According to the data obtained, the increase in the delay coefficient above the value does not lead to a significant change in the characteristics of chaotic processes. This parameter can be used to switch from harmonic rotation frequency to chaotic mode. For the considered system of vibrating tamper it is expedient to maintain within the limits $\left\{K_{\tau} \in \mathbb{R} \mid 2 \leq K_{\tau} \leq 3\right\}$.

The last parameter of the law (7), which is to be analyzed, is the rate of feedback amplification at rotation frequency $K_{\omega}$. In Tabl. 3 shows the parameters of the rotation frequency of the electric drive and the position of the vibrating tamper when the delay time $K_{\omega}$ is changed.

Table 3 - Modeling results for $K_{\omega}=$ var , $\tau=0.4 \mathrm{~s}=$ const,$K_{\tau}=3=$ const

\begin{tabular}{|l|c|c|c|c|c|}
\hline$K_{\omega}$ & $\begin{array}{c}\omega_{\min }, \\
\mathrm{rpm}\end{array}$ & $\begin{array}{c}\omega_{\max }, \\
\mathrm{rpm}\end{array}$ & $\begin{array}{c}\Delta \omega, \\
\mathrm{rpm}\end{array}$ & $\begin{array}{c}\bar{\omega}, \\
\mathrm{rpm}\end{array}$ & $\begin{array}{c}\Delta x, \\
\mathrm{~mm}\end{array}$ \\
\hline 1 & 142.93 & 170.52 & 27.59 & 159.92 & 7.39 \\
\hline 1.1 & 134.19 & 172.18 & 37.98 & 157.71 & 7.56 \\
\hline 1.2 & 132.37 & 173.39 & 41.02 & 153.82 & 7.93 \\
\hline 1.3 & 130.38 & 174.91 & 44.53 & 151.49 & 8.08 \\
\hline 1.4 & 128.67 & 176.09 & 47.43 & 150.81 & 8.28 \\
\hline
\end{tabular}

The increase the coefficient $K_{\omega}$ leads to an equations of the range of change in the rotation frequency. The change in the range, in contrast to the increase in lag $\tau$ is due to the simultaneous reduction of the lower limit and the increase of the upper. The average value of the rotation frequency thus decreases. This leads to an increase in the oscillation amplitude of the vibration damper.

After establishing the character of the influence of the parameters of the law (7) on the chaotic operation mode, we introduce into the model element that limits the supply voltage within the limits $\left\{U \in \mathbb{R} \mid 0 \leq U \leq U_{\text {nom }}\right\}$. In Fig. 9, 10 are graphs with the following parameters: $\tau=0.3 \mathrm{~s}, K_{\tau}=3, K_{\omega}=2$. 


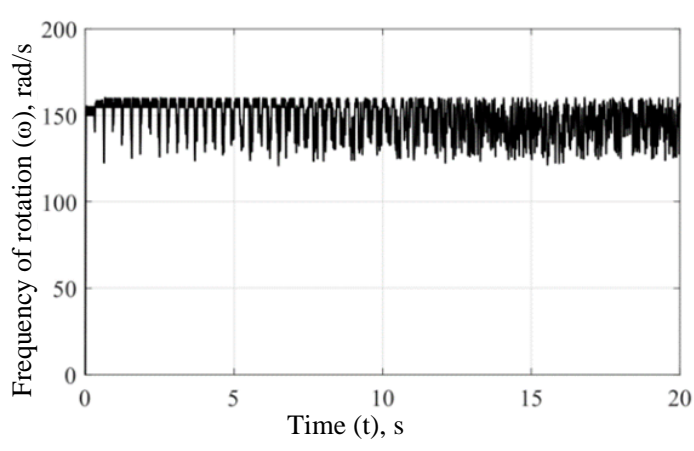

Figure 9 - Hourly realization of chaotic mode on the rotation frequency in a vibrating tamper electric motor at $\tau=0.4 \mathrm{~s}, K_{\tau}=3, K_{\omega}=2$

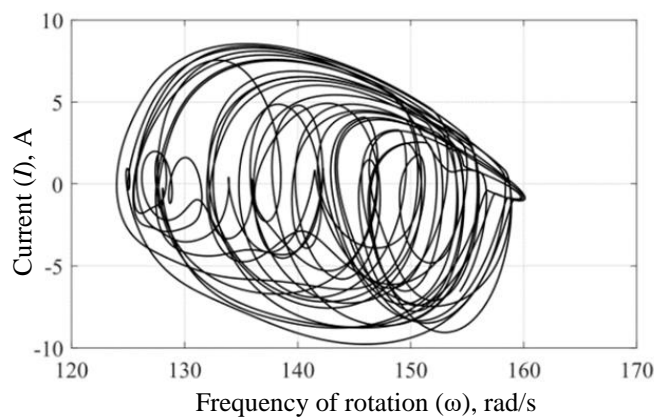

Figure 10 - A phase portrait of a vibrating tamper in a chaotic operating mode at $\tau=0.4 \mathrm{~s}, K_{\tau}=3, K_{\omega}=2$

When the power supply voltage is limited, the chaotic character of the electric drive movement occurs with some delay compared to the system in which the voltage can acquire arbitrary values.

CONCLUSIONS. The expediency of using chaotic modes of electric drives for improving the quality of lining of crucible induction furnaces during the production of pig iron is substantiated. To increase the reliability of electromechanical equipment, it is proposed to replace a mechanical vibration system with a triple pendulum controlled electric drive with special properties.

The mathematical model of a vibrating tamper with a direct current electric drive is developed.

To form the chaotic motion of a vibrating tamper, it is proposed to use the sinusoidal function from the delay of the feedback on the rotation frequency of the electric drive.

The mathematical model of the closed electromechanical system examines the influence of the control system parameters on the operating modes of the electromechanical system, the possibility of the occurrence of chaotic operating modes of the electromechanical system, the influence of setting the closed control system on the characteristics of the rotation frequency of the electromechanical system is considered.

\section{REFERENCES}

1. Sassa, V. (1989), Futerovka induktsionnykh elektropechey [Lining of induction electric furnace], Metallurgy, Moscow. (in Russian)

2. Long, Y. (2001), "Chaotic dynamics \& compaction engineering”, In Proceedings of International Conference on Soft Soil Engineering, Lisse, Netherlands, pp. 91-95.

3. Chau, K.T. and Wang, Zheng (2011), Chaos in electric drive systems: analysis, control and application, John Wiley \& Sons, Singapore.

4. Ren, H.P. and Han, C.Z. (2006), "Chaotifying Control of Permanent Magnet Synchronous Motor", In Proceedings of 2006 CES/IEEE 5th International Power Electronics and Motion Control Conference, pp. 1-5.

5. Ye, Z.-Y., Yang, G. and Deng, C.-B. (2011), "Time-delay feedback control in a delayed dynamical chaos system and its applications", Chinese Physics B, Vol. 20, no. 1, 010207.

6. Wang, X.F., Zhong, G.-Q., Tang, K.-S., Man K.F. and Liu, Z.-F. (2001), "Generating Chaos in Chua's Circuit via Time-Delay Feedback", IEEE transactions on circuits and systems - I: Fundamental theory and applications, Vol. 48, no. 9, pp. 1151-1156.

7. Chau, K.T. and Wang, Z. (2008), "Anti-control of a permanent-magnet DC motor system for vibratory compactors", Chaos, Solitons and Fractals, Vol. 36, pp. 694-708.

8. Ge, Z.-M., Cheng, J.-W. and Chen, Y.-S. (2004), "Chaos anticontrol and synchronization of three time scales brushless DC motor system", Chaos, Solitons and Fractals, Vol. 22, pp. 1165-1182.

9. Lu, Y., Zhou, T., Chen, G. and Yang, X. (2002), "Generating chaos with a switching piecewise-linear controller", Chaos, Vol. 12, no. 2, pp. 344-349.

10. Kelly, S.G. (2000), Fundamentals of mechanical vibrations, McGrow-Hill, Singapore.

11. Hatch, M.R. (2000), Vibration simulation using MATLAB and ANSYS, Chapman and Hall/CRC Press, Boca Raton, Florida.

12. Chornyi, O.P., Luhovoi, A.V., Rodkin, D.Y., Sysiuk, H.Yu. and Sadovoi, O.V. (2001), Modelyuvannya elektromekhanichnykh system [Electromechanical systems simulation], Kremenchuk. (in Ukrainian)

13. Lynch, S. (2014), Dynamical Systems with Applications using MATLAB, Springer, Basel, Switzerland.

14. Syahrian, N. (2017), Permanent Magnet DC Brush Motors Technical Data Sheet, C23, 34, 42 Series, Moog Components Group, pp. 193-200. 


\section{ИССЛЕДОВАНИЕ ЭЛЕКТРОМЕХАНИЧЕСКОЙ СИСТЕМЫ ВИБРОУПЛОТНИТЕЛЯ С ХАОТИЧЕСКИМ КВАЗИУСТАНОВИВШИМСЯ РЕЖИМОМ РАБОТЫ}

\section{А. Ю. Михайленко, В. К. Тытюк}

Государственное высшее учебное заведение «Криворожский национальный университет» ул. Виталия Матусевича, 11, г. Кривой Рог, 50027, Украина. E-mail: epem.mykhailenko@gmail.com

А. П. Черный, Е. В. Бурдильная, А. П. Оксанич

Кременчугский национальный университет имени Михаила Остроградского

ул. Первомайская, 20, г. Кременчуг, 39600, Украина. E-mail: alekseii.chornyi @gmail.com

Работа посвящена вопросу исследования возможности создания хаотических режимов движения электромеханической системы виброуплотнителя футеровки тигельных индукционных печей с целью повышения качества футеровки, которая во многом определяет технико-экономические показатели процесса производства чугуна. Предложен метод формирования хаотического режима работы электропривода виброуплотнителя путем применения синусоидальной функции от запаздывания в цепи обратной связи по скорости электропривода. Установлена зависимость показателей хаотического режима работы от параметров замкнутой системы управления при работе электропривода как в системе с источником питания бесконечной мощности, таки с учетом ограничения форсировки питающего напряжения. В исследовании поставленных задач использовались общие методы теории электропривода, электротехники и математического моделирования. Составление уравнений математической модели виброуплотнителя с электроприводом постоянного тока основано на применении апробированных законов механики и электротехники. Решение полученных уравнений и визуализация полученных результатов выполнена в среде MATLAB/Simulink. Разработана математическая модель механической системы виброуплотнителя с учетом демпфирующей способности футеровки. В качестве электропривода виброуплотнителя принят двигатель постоянного тока независимого возбуждения. В результате анализа известных методов возбуждения режима хаотических колебаний в электромеханических системах для виброуплотнителя футеровки была использована синусоидальная функция от задержанной обратной связи по скорости электропривода. Приведены результаты математического моделирования режимов работы электромеханической системы виброуплотнителя с замкнутой системой управления, определены условия возникновения хаотического режима работы, рассмотрена зависимость показателей хаотического режима работы от настроек цепи обратной связи замкнутой системы управления. Использование предложенного подхода позволит упростить конструкцию механической части электропривода виброуплотнителя, повысить плотность футеровки тигельных индукционных печей, улучшить технико-экономические показатели процесса производства чугуна.

Ключевые слова: виброуплотнитель, хаос, электропривод, обратная связь, запаздывание, MATLAB.

Стаття надійшла 23.08.2018. 